\title{
Phytophages of linden under the conditions of Grodno Ponemany (Belarus) and Krasnodar (Russia)
}

\author{
Igor Popov ${ }^{1, *}$, Aleksandra Rhyzhaya ${ }^{2}$, Ekaterina Hliakouskaya ${ }^{2}$, and Oksana Kremneva ${ }^{3}$ \\ ${ }^{1}$ I.T. Trubilin Kuban State Agrarian University, 13 Kalinin st., Krasnodar, 350044, Russia \\ ${ }^{2}$ Yanka Kupala Grodno State University, 22 Ozheshko st., Grodno, 230023, Belarus \\ ${ }^{3}$ All-Russian Research Institute of Biological Plant Protection, Krasnodar, 350039, Russia
}

\begin{abstract}
Comparative studies of linden phytophages in the urban landscapes of Grodno Ponemany (Belarus) and Krasnodar (Russia) have been carried out. 22 arthropod species were revealed, including 6 species of herbivorous ticks and 16 species of insects. Among these organisms, 18 species are representatives of the native fauna, 4 are invasive, while the invaders in the Grodno Ponemany and in Krasnodar are different (two species each). In Grodno Ponemany, oligophages prevail, in Krasnodar, the proportion of polyphages is high. The invasive species Phyllonorycter issikii (Kumata) and native species of gall mites are the most harmful in Belarus. The significance of the invaders in Krasnodar is much lower, and Metcalfa pruinosa Say, and Hyphantria cunea Drury cause significant damage to linden only in the years of sharp increase in number. In Krasnodar, linden spider mite - Schizotetranychus tiliarium (Hermann) is the most harmful, populating $100 \%$ of linden trees older than 10 years. Almost all polyphages, with the exception of the invaders identified for Krasnodar, exhibit moderate or low harmfulness.
\end{abstract}

\section{Introduction}

Currently, in Europe, including Belarus and Russia, a wide range of woody plants is used in green building. These include small-leaved (heart-shaped, or winter) linden - Tilia cordata Mill., 1768 and broad-leaved (large-leaved) linden - Tilia platyphyllos Scop., 1772. The habitat of small-leaved linden extends from South Britain to the European part of Russia, the Caucasus, Bulgaria, Italy and Spain, and it also continues to expand due to artificial distribution $[1,2]$. This is a deciduous tree, up to $20-38 \mathrm{~m}$ tall with a hipped crown. The leaves are alternate, heart-shaped, long-leaved, dentate, with a pointed apex, green above, bluish below. The habitat of broad-leaved linden is Western, Central and Southern Europe. This tree is up to $40 \mathrm{~m}$ tall, with a dense, wide-pyramidal crown, with reddish-brown, pubescent, less often bare young shoots. Leaves are up to $14 \mathrm{~cm}$, round-ovate, dark green

${ }^{*}$ Corresponding author: ibento@yandex.ru 
above, bare, paler below, with bundles of light hairs in the corners of the veins, on petioles 2-6 cm long [3]. The leaves bloom one to two weeks later than that of small-leaved linden.

Linden is a characteristic ancient element of the European flora, which has not only decorative, but also scientific, agricultural, and medical significance [4-9].

For many species of pests, regional characteristics of the climate and phenology of the host plant are of great importance, which can affect the characteristics of biology and ecology, the type of damage [10-12]. The research is aimed at the identification of the taxonomic composition of linden pests (T. cordata, T. platyphyllos), as well as at the comparing the extent of linden damage by arthropod phytophage pests of urban greenery in the territory of Grodno Ponemany (Belarus) and Krasnodar (Russia). We also assessed the role of invasive elements in damage to linden trees on the territory of Krasnodar and Grodno Ponemany.

\section{Materials and methods}

This research is based on the results of the targeted surveys of linden trees plantings $(T$. cordata, T. platyphyllos) performed during the field seasons 2016-2019 on the territory of urban green spaces of the Grodno Ponemany (the cities of Grodno, Skidel, Mosty, Lida and the urban village of Porozovo), as well as the city of Krasnodar. The collection of material for entomo-phytopathological studies was carried out during a visual inspection of trees of various ages and sizes for the presence of arthropod phytophage pests and damage caused by them. Also, light traps, which have proven themselves in a number of entomofauna studies in agrocoenoses of Krasnodar Krai, were used to collect insects [13, 14]. Plant fragments with phytophages and damaged structures were collected and herbarized for subsequent laboratory analysis. The identification of the taxonomic affiliation of arthropods was carried out using thematic identifier atlases, reference materials, and specialized Internet sources. The harmfulness level was assessed according to generally accepted methods.

\section{Results and discussion}

According to the studies carried out on lindens (T. cordata, T. platyphyllos) in the green spaces of Grodno Ponemany and Krasnodar, 22 species of arthropod pests from two classes, six orders and thirteen families were found (Table 1).

Table 1. Taxonomic composition and brief description of arthropod pests of lindens (Tilia cordata and Tilia platyphyllos) in the green spaces of Grodno Ponemany (Belarus) and Krasnodar (Russia)

\begin{tabular}{|c|c|c|c|c|}
\hline \multirow{2}{*}{ Pest families and species } & \multicolumn{2}{|c|}{ Grodno Ponemany } & \multicolumn{2}{|c|}{ Krasnodar } \\
\hline & T.cordata & T.platyphyllos & T.cordata & T.platyphyllos \\
\hline \multicolumn{5}{|c|}{ Eriophyidae } \\
\hline $\begin{array}{l}\text { Eriophyes leiosoma } \\
\text { (Nalepa, 1892) }\end{array}$ & $+++^{*}$ & +++ & + & + \\
\hline $\begin{array}{l}\text { Eriophyes tiliae } \\
\text { (Pagenstecher, 1857) }\end{array}$ & +++ & +++ & + & + \\
\hline $\begin{array}{l}\text { Eriophyes tiliaenervalis } \\
\text { (Nalepa, 1918) }\end{array}$ & ++ & - & - & - \\
\hline $\begin{array}{l}\text { Phytoptustetra trichus } \\
\text { (Nalepa, 1890) }\end{array}$ & +++ & +++ & + & + \\
\hline $\begin{array}{l}\text { Eriophyes exilis (Nalepa, } \\
\text { 1892) }\end{array}$ & ++ & - & - & - \\
\hline
\end{tabular}


Continuation of the table1

\begin{tabular}{|c|c|c|c|c|}
\hline \multicolumn{5}{|c|}{ Tetranychidae } \\
\hline $\begin{array}{l}\text { Schizotetranychus } \\
\text { tiliarium (Hermann, 1804) }\end{array}$ & - & - & ++++ & ++++ \\
\hline \multicolumn{5}{|l|}{ Aphididae } \\
\hline $\begin{array}{l}\text { Eucallipterus tiliae } \\
\text { (Linnaeus, 1758) }\end{array}$ & ++ & - & +++ & +++ \\
\hline \multicolumn{5}{|l|}{ Flatidae } \\
\hline $\begin{array}{l}\text { Metcalfa pruinosa Say, } \\
1830\end{array}$ & - & - & + & + \\
\hline \multicolumn{5}{|l|}{ Buprestidae } \\
\hline $\begin{array}{l}\text { Trachys minutus } \\
\text { (Linnaeus, 1758) }\end{array}$ & + & - & - & - \\
\hline \multicolumn{5}{|l|}{ Bucculatricidae } \\
\hline $\begin{array}{l}\text { Bucculatrix thoracella } \\
\text { (Thunberg, 1794) }\end{array}$ & + & + & - & - \\
\hline \multicolumn{5}{|l|}{ Gracillariidae } \\
\hline $\begin{array}{l}\text { Stigmella tiliae (Frey, } \\
1856 \text { ) }\end{array}$ & - & + & - & - \\
\hline $\begin{array}{l}\text { Phyllonorycter issikii } \\
\text { (Kumata, 1963) }\end{array}$ & ++++ & ++++ & - & - \\
\hline \multicolumn{5}{|c|}{ Arctiiade } \\
\hline $\begin{array}{l}\text { Hyphantria cunea Drury, } \\
1773\end{array}$ & - & - & + & + \\
\hline \multicolumn{5}{|l|}{ Limantriidae } \\
\hline $\begin{array}{l}\text { Lymantria dispar } \\
\text { (Linnaeus, 1758) }\end{array}$ & - & - & + & + \\
\hline \multicolumn{5}{|l|}{ Sphingidae } \\
\hline $\begin{array}{l}\text { Mimas tiliae (Linnaeus, } \\
1758 \text { ) }\end{array}$ & - & - & + & + \\
\hline \multicolumn{5}{|l|}{ Noctuidae } \\
\hline $\begin{array}{l}\text { Cosmia trapezina } \\
\text { (Linnaeus, 1758) }\end{array}$ & - & - & + & + \\
\hline $\begin{array}{l}\text { Amphipyra pyramidea } \\
\text { (Linnaeus, 1758) }\end{array}$ & - & - & + & + \\
\hline \multicolumn{5}{|c|}{ Tenthredinidae } \\
\hline $\begin{array}{l}\text { Caliroa annulipes (Klug, } \\
1816 \text { ) }\end{array}$ & ++ & - & + & - \\
\hline $\begin{array}{l}\text { Parna apicalis (Brischke, } \\
\text { 1888) }\end{array}$ & + & - & - & - \\
\hline \multicolumn{5}{|c|}{ Cecidomyiidae } \\
\hline $\begin{array}{l}\text { Contarinia tiliarum } \\
\text { (Kieffer, 1890) }\end{array}$ & - & ++ & - & - \\
\hline $\begin{array}{l}\text { Dasineura tiliae (Schrank, } \\
1803 \text { ) }\end{array}$ & ++ & ++ & - & - \\
\hline $\begin{array}{l}\text { Didymomyia tiliacea } \\
\text { (Bremi, 1847) }\end{array}$ & ++ & - & - & - \\
\hline
\end{tabular}


Among the arthropod pests the family of gall mites (Acariformes: Eriophyidae) is represented with the largest number -5 species. The three species belong to the family of gall midges (Diptera: Cecidomyiidae), and the family of midget moths (Lepidoptera: Gracillariidae) and the sawflies family (Hymenoptera: Tenthredinidae) are represented with two species each. Of the representatives of the remaining families, only 1 species was found.

It was found that small-leaved linden under the conditions of the Grodno Ponemany is damaged by 14 species of arthropod pests, while broad-leaved linden is damaged only by seven species. Phylobiont forms (93\%) living on leaf blades predominate. One species of caulobiont $(7 \%)$, linden petiole gall midge (C. tiliarum), forming galls $4-15 \mathrm{~mm}$ in size, was noted on leaf petioles and on young shoots of broad-leaved linden (T. platyphyllos).

Small-leaved linden is damaged by 8 species (C. annulipes, D. tiliacea, E. exilis, E. tiliaenervalis, E. tiliae, P. apicalis, St. tiliae, Tr. minutus) that are not found on broadleaved linden. The level of harmfulness of linden pests in the green spaces of the Grodno Ponemany varies from low to extremely high. In most species, it was rated as moderate (2 points on a 4-point scale). The invader linden midget moth (Ph. issikii), a species of Far Eastern origin is characterized by the extremely high level of harmfulness $[15,16]$. In Belarus, it behaves as a strict oligophage, feeding on various representatives of the linden genus (Tilia spp.). In the green spaces of the Grodno Ponemany this species is noted on the small-leaved and broad-leaved lindens. Caterpillars of this miner form low-sided, ovalshaped, filmy mines located between the lateral veins of the leaf. The mine epidermis does not have folds, slightly spaced from the inner surface and often has a brownish color. Damage becomes clearly visible from the upper side of the leaf blade only at the last stages of the caterpillars development. A leaf is often deformed in the area of the mine. In Krasnodar, this species of pest has not yet been identified.

Very important phytophages are several species of mites [17]. Linden gall mites (E. tiliae), linden felt mites (E. leiosoma), and linden edge mites (Ph. tetratrichus), found on both small-leaved and broad-leaved lindens, are widespread in almost all plantations of lindens. In addition, an invasive species among gall mites, a linden felt thin mite (E. exilis), which has a Far Eastern origin, was found on small-leaved linden. Mites initiate the formation of small round whitish or reddish bulges in the corners of the veins on the upper side of the leaf blade. From below, they are corresponded by tufts of cylindrical pointed hairs ("brushes"). In the green spaces of the Grodno Ponemany it shows moderate harmfulness. In Krasnodar, there is much less influence of gall mites. For example, a linden gall mite is very rare, the occupation is less than $1 \%$, and even on the affected trees the species is found only on a small number of branches, usually in the lower part of the crown, without spreading over the plant for several years of observation. Removing of the affected branches by complete pruning destroys the mite population. The remaining gall mites also show low harmfulness, and the invader E. exilis was not found in the city.

Unlike the Grodno Ponemany, in Krasnodar, the most common phytophage inhabiting $100 \%$ of linden trees older than 10 years of both species is the spider linden mite $S$. tiliarium, it affects all the leaves. Young plants are characterized by a lower occupation ( 0 $20 \%$ ), which indicates the active mite spreading in urban plantations, but not in seedlings nurseries. Visible damage, which appears as chlorotic spots from the beginning of June, covers from 5 to $80 \%$ of the surface area of the leaf blade, causing necrosis and leaf decay by the end of August.

An important invasive species in Krasnodar is the citrus flatid leafhoppers ( $M$. pruinosa), which has been observed in the city since 2008 and is able to populate individual plants very densely. With a large number of larvae, the leaves curl, their growth stops. In the most severe cases, complete defoliation of individual shoots is possible by the end of May. The greatest harmfulness of this species was observed in 2010-2016, which is 
characteristic of invaders, after which a complex of entomophages was formed, primarily several species of ladybird (Coccinellidae), including both native species and the invasive Harmonia axyridis Pallas, 1773, which are capable to suppress pest foci for a short period of time.

All other phytophages, both oligophages and polyphages, manifest moderate or low harmfulness.

Most of the identified phytophage species are pests of agricultural crops, as well as additional hosts and victims of many species of entomophages.

\section{Conclusions}

As a result of the studies, 22 species of phytophages were identified, which belong to various systematic and ecological groups. Among them, 18 species are native, and 4 are adventive. In Grodno Ponemany, the Far Eastern invader Ph. issikii (Kumata) manifests the highest harmfulness for linden. In Krasnodar, invaders harm only in case of mass development of local populations. In this case, the highest harmfulness is demonstrated by the native species of linden mites - Sch.tiliarium (Hermann). The remaining representatives of the native fauna are of limited distribution and low harmfulness. The accumulation of entomophages, primarily ladybirds, on linden in spring, contributes to their further spread to other foci of polyphagous pests within the city, as well as to agrocenoses beyond it, which contributes to the biological regulation of the number of phytophages.

The studies of linden phytophages were carried out with the financial support from the Russian Foundation for Basic Research and the Administration of Krasnodar Territory, project 19-44-230004 r_a.

\section{References}

1. D. Pigott, Cambridge University Press. 395 (2007) https://www. cambridge.org/core/books/limetrees-and-basswoods/european-and-western-asian-taxa/5 AAEB4D9A82974F9BE110F5F6D2E585C

2. I.T. Kishchenko, Bulletin of the Northern (Arctic) Federal University. Series: Natural Sciences. , 56-65 (2015) https://aer.narfu.ru/upload/iblock/601/56_65.pdf

3. M. Kupryjanowicz, M. Fiłoc, W.Granoszewski, Quaternary International. 467, 107 116 (2018) https://www.researchgate.net/publication/323443718 httpsdoiorg101016jpalaeo $\underline{201802001}$

4. D.V. Veselova, E.F. Stepanova, Pharmacy and Pharmacology. 4(1), 4-9 (2016) https://www.researchgate.net/publication/315475923 httpdxdoiorg10191632307-92662016-4-6-4-32

5. M.C. Noguerón-Merino, E. Jiménez-Ferrer, A. Zamilpa, J. Tortoriello, M. HerreraRuiz, R. Román-Ramos, Journal of ethnopharmacology. 164, 319-327 (2015) https: //www.researchgate.net/publication/323443718 httpsdoiorg101016jpalaeo201802001

6. E.A. Zhukova, Bulletin of the St. Petersburg Forestry Academy. 228, 88-103 (2019) https://spbftu.ru/wp-content/uploads/2019/09/228-05.pdf

7. H. Myers Judith, M. Sarfraz Ranau, The Ecological Society of Korea. 62, 207-230 (2017) https://www.annualreviews.org/doi/abs/10.1146/annurev-ento-010715-023826

8. M. Kopecká, H. Nagendra, A. Millington, Land multidisciplinary urban land systems: An Ecosystems Perspective/ Digital Publishing Institute (MDPI), 7(5), 2018 https://www.mdpi.com/2073-445X/7/1/5 
9. S.V. Pestov, I.G. Tychinkina, S.Yu. Ogorodnikova, Bulletin of Tomsk State University. Biology. 44, 188-201 (2018) http://journals.tsu.ru/biology/ $\underline{\text { \&journal page }=\text { archive \&id }=1791 \& \text { article } \mathrm{id}=39522}$

10. M.-Y. Huang, H.-M. Chou, Y.-T Chang., C.-M. Yang, J. of Asia-Pacific Entomology. 17(2), 151-154 (2014) https://link.springer.com/content/pdf $/ 10.1016 \%$ 2Fj.jasms.2005.12.002.pdf

11. R. M. S. Isaias, D.C. Oliveira, A. S. F.P. Moreira, G.L.G. Soares, R.G.S. Carneiro, Biochimica et Biophysica Acta. 1850(8), 1509-1517 (2015) https://www.rug.nl/ research/portal/files/2810915/2007BiochimBiophysActaSani.pdf

12. A. Pachkin, O. Kremneva, I. Popov, R. Zelensky, A.Kurilov, R. Danilov Comparative assessment of the efficiency of light traps of various design in corn agrocenosis // IOP Conference Series: Earth and Environmental Science, 403 (2019) 012141. https://iopscience.iop.org/issue/1755-1315/403/1

13. A.A. Pachkin, I.B. Popov, O. Yu. Kremneva, R.A. Zelenskiy, Achievements of Science and Technology of AICis. 12, 73-76 (2019)

14. I.V. Ermolaev, O.V. Sidorova, Entomological Review. 92(4), 403-408 (2012) https://link.springer.com/article/10.1134\%2FS0013873812040057

15. I.V. Ermolaev, E.A. Rubleva, S.L. Rysin, M.V. Ermolaeva, Russian journal of biological invasions. 9(3), 205-214 (2018) https://link.springer.com/content/pdf/ 10.1134\%2FS1064229310130016.pdf

16. A. Skoracka, L. Smith, G. Oldfield, M. Cristofaro, J. W. Amrine, Experimental and Applied Acarology. 51, 93-113 (2010) https://link.springer.com/article/10.1007/s10493009-9328-1

17. K. Faleńczyk-Koziróg, T. Marquardt, S. Kaczmarek, Biological Letters. 51(1), 3-6 (2014) https://journals.indexcopernicus.com/search/article?articleId=1316070 